\title{
Chimeric Antigen Receptor T-Cell Therapy for Lymphomas
}

Hospital Pharmacy

2017, Vol. 52(7) 469-470

(c) The Author(s) 2017

Reprints and permissions:

sagepub.com/journalsPermissions.nav

DOI: $10.1177 / 0018578717726517$

journals.sagepub.com/home/hpx

@SAGE

\author{
Benjamin Jolley' and Scot Walker ${ }^{2}$
}

\begin{abstract}
It is estimated that $2.1 \%$ of the population of the United States will develop non-Hodgkin lymphoma (NHL) in a lifetime. With treatment, $71 \%$ of patients with NHL live to 5 years. Because current drugs used for treatment do not cure all patients and cause serious adverse effects, new strategies have been studied to treat lymphoma. One new pharmacologic strategy is to use chimeric antigen receptor T-cell (CAR T-cell) therapy. CAR T-cell therapies are very potent. As a class, the CAR T-cell therapies have induced complete remission in $50 \%$ to $80 \%$ of patients. Most patients using CAR T-cell therapies develop cytokine release syndrome, with about $I$ in 3 having a severe form of the syndrome. This article will briefly review CAR T-cell therapies in development.
\end{abstract}

\section{Keywords}

oncology, investigational drugs, formulary management/P\&T

\section{Epidemiology}

Non-Hodgkin lymphoma (NHL) affects about $2.1 \%$ of the population with an estimated 661,996 patients with NHL. It accounts for $4.3 \%$ of new cancer diagnoses, and $3.4 \%$ of cancer deaths. It is more prevalent in men than in women. ${ }^{1}$ With treatment, $71 \%$ of patients with NHL survive to 5 years. NHL is responsible for 20,140 deaths annually. The direct medical cost to Medicare per case per year due to treatment of NHL is about $\$ 49,000$ annually. ${ }^{2}$ NHL is more common in patients with immunosuppressed states, such as transplant recipients, AIDS patients, and patients on chronic glucocorticoids.

\section{Current Treatment}

NHL can be treated with radiation therapy, chemotherapy, and biologic therapy. The specific type of therapy depends on the type of NHL. Indolent NHL is frequently treated with a single agent. Aggressive NHL is generally treated with complex combination chemotherapy and biologic therapy. Many types of NHL are treated with rituximab, cyclophosphamide, doxorubicin, vincristine, and prednisone (R-CHOP), given in 4 to 6 cycles. ${ }^{3}$ R-CHOP has many short- and long-term toxicities, including increased risk of infection, bruising and bleeding, mucositis, and cardiotoxicity. About $40 \%$ to $50 \%$ of patients with diffuse large B-cell lymphoma will relapse or not respond following treatment with R-CHOP. ${ }^{4}$ The side effect profile and relatively high rate of relapse and nonresponse to this first-line treatment suggest the need for new therapeutic strategies.

\section{New Treatment Options}

Chimeric antigen receptor T-cell (CAR T-cell) therapy is a term that describes a range of immunotherapies. In essence, CAR T-cell therapy uses autologous $\mathrm{T}$ cells, which are modified with a vector to produce a CAR specific to a tumor antigen, creating a $\mathrm{T}$ cell that is designed to attack cells bearing that antigen. In theory, this strategy could be applied to any tumor antigen, but the products closest to market all target CD19 (Table 1). CD19 is expressed on the surface of B cells, so B cell leukemias and lymphomas are the target of these CAR T products. ${ }^{5}$ In one phase II trial, axicabtagene induced complete remission of NHL in 54\% of patients at 6 months. Tisagenlecleucel showed $82 \%$ complete remission of refractory B-cell acute lymphoblastic leukemia (ALL) in a phase II study. All drugs in this class have the adverse effect of cytokine release syndrome (CRS), with about one-third of patients having severe CRS. One CAR T-cell product, JCAR015, was abandoned due to patient deaths during trials due to CRS and cerebral edema. Tisagenlecleucel has also caused B-cell aplasia, requiring treatment with intravenous immunoglobulin (IVIG). These safety concerns are the primary barrier to potential Food and Drug Administration (FDA) approval

\footnotetext{
'St. Louis College of Pharmacy, MO, USA

${ }^{2}$ Prescribe Right, LLC, Wildwood, MO, USA

Corresponding Author:

Scot Walker, Chief Executive Officer, Prescribe Right, LLC, 1602 Westglen Farms Dr, Wildwood, MO 630I I, USA.

Email: scot.walker@prescriberight.com
} 
Table I. CAR T-Cell Therapies in Development.

\begin{tabular}{|c|c|c|c|}
\hline Generic name & Sponsor & CAR target & Comments \\
\hline Axicabtagene & Kite Pharma & CDI9 & $\begin{array}{l}\text { Axicabtagene was granted a priority review and has a PDUFA date of } 11 / 29 / 17 \text {. } \\
\text { In one trial of } 101 \mathrm{NHL} \text { patients, } 54 \% \text { achieved complete response at } 6 \\
\text { months. Kite estimates the manufacturing turn-around time to be } 22 \text { days. }\end{array}$ \\
\hline Tisagenlecleucel & $\begin{array}{l}\text { Novartis } \\
\text { Pharmaceuticals }\end{array}$ & CDI9 & $\begin{array}{l}\text { An FDA subcommittee recommended approval of tisagenlecleucel in a } 10-0 \\
\text { vote on } 7 / 12 / 17 \text {, with a PDUFA date of } 10 / 3 / 17 \text {. Novartis is estimating the } \\
\text { manufacturing turn-around time to be } 22 \text { days, which includes } 10 \text { to } 12 \text { days } \\
\text { for cell processing. In a } 50 \text {-patient phase II trial, } 82 \% \text { of patients achieved a } \\
\text { complete response. In a } 60 \text {-patient ALL trial, overall survival was } 65 \% \text { at } 24 \\
\text { months. }\end{array}$ \\
\hline JCAROI 7 & Juno Therapeutics & CDI9 & $\begin{array}{l}\text { Analysts estimate that JCAROI } 7 \text { may be available in mid-20I8. Juno plans a } \\
\text { phase III trial in DLBCL patients in the second half of } 2017 \text {. In a } 44 \text {-patient } \\
\text { trial, } 66 \% \text { of patients had an objective response, and } 50 \% \text { achieved a complete } \\
\text { response. }\end{array}$ \\
\hline bb2I2I & bluebird bio & BCMA & $\begin{array}{l}\text { Bluebird announced that interim results from a phase I trial showed that } 15 \text { of } \\
\text { I } 5 \text { patients with relapsed multiple myeloma achieved an objective response. }\end{array}$ \\
\hline LCAR-B38M & $\begin{array}{l}\text { Nanjing Legend } \\
\text { Biotech }\end{array}$ & BCMA & $\begin{array}{l}\text { Legend announced that interim results from a phase I Chinese trial showed that } \\
33 \text { of } 35 \text { patients with relapsed multiple myeloma achieved clinical remission } \\
\text { within } 2 \text { months. }\end{array}$ \\
\hline
\end{tabular}

Source. Information adapted from the Prescribe Right Pharmaceutical Pipeline Tracker database. ${ }^{8}$

Note. CAR = chimeric antigen receptor; $\mathrm{CDI} 9$ = cluster of differentiation 19; PDUFA = Prescription Drug User Fee Act; NHL = non-Hodgkin lymphoma; $\mathrm{DLBCL}=$ diffuse large B-cell lymphoma; FDA = Food and Drug Administration; $\mathrm{ALL}=$ acute lymphoblastic leukemia; $\mathrm{BCMA}=\mathrm{B}-\mathrm{cell}$ maturation antigen; ORR = objective response rate.

of CAR T-cell products. These products will likely be priced up to $\$ 500,000$ per treatment course based on analyst predictions. ${ }^{6}$ An analysis by the United Kingdom's National Institute for Health and Care Excellence suggested that these therapies could be worth up to $\$ 649,000$ for young patients with acute lymphoblastic leukemia. ${ }^{7}$ The CRS side effect has generally been treated in clinical trials with tocilizumab, which adds to the cost of this therapy. Tocilizumab costs about $\$ 1000$ per dose. IVIG costs between $\$ 1000$ and $\$ 10,000$ per dose.

\section{Authors' Note}

Information is summarized from selected materials; additional information may be available from other sources. Due to the preapproval nature of the information, non-peer-reviewed data may be utilized. The information provided is meant to provide a way to assess the development status of a new drug and should not be used in making patient care decisions.

\section{Declaration of Conflicting Interests}

The author(s) declared no potential conflicts of interest with respect to the research, authorship, and/or publication of this article.

\section{Funding}

The author(s) received no financial support for the research, authorship, and/or publication of this article.

\section{References}

1. SEER. Cancer stat facts: non-Hodgkin lymphoma. Bethesda, MD: National Cancer Institute. http://seer.cancer.gov/statfacts/ html/nhl.html. Accessed July 09, 2017.

2. Xie L, Keshishian A, Du J, Baser O. Assessing the economic burden of U.S. Medicare patients diagnosed with nonHodgkin's lymphoma. Value in Health. 2015;18(3):A200. doi:10.1016/j.jval.2015.03.1158.

3. Chan A, Sessions J. Lymphomas. In: DiPiro JT, Talbert RL, Yee GC, Matzke GR, Wells BG, Posey L, eds. Pharmacotherapy: A Pathophysiologic Approach. 10 ed. New York, NY: McGrawHill. http://accesspharmacy.mhmedical.com/content.aspx?book id=1861\&sectionid=133894009. Accessed July 9, 2017.

4. Raut LS, Chakrabarti PP. Management of relapsed-refractory diffuse large B cell lymphoma. South Asian J Cancer. 2014;3(1):66-70.

5. McCain J. Chimeric antigen receptor T-cell therapy: the next big thing faces challenges. Managed Care. https://www.managedcaremag.com/archives/2017/5/chimeric-antigen-receptort-cell-therapy-next-big-thing-faces-challenges. Published June 6, 2017. Accessed July 9, 2017.

6. Clarke T. Pioneering cancer gene therapy by Novartis backed by US panel. Reuters. http://www.reuters.com/article/us-novartiscancer-idUSKBN19X2OZ. Accessed July 24, 2017.

7. Hettle R, Corbett M, Hinde S, et al. The assessment and appraisal of regenerative medicines and cell therapy products: an exploration of methods for review, economic evaluation and appraisal. Health Technol Assess. 2017;21(7):1-204.

8. Prescribe Right. Pharmaceutical pipeline tracker. http://www. prescriberight.com/pharmaceutical-pipeline-tracker.html. Accessed July 24, 2017. 